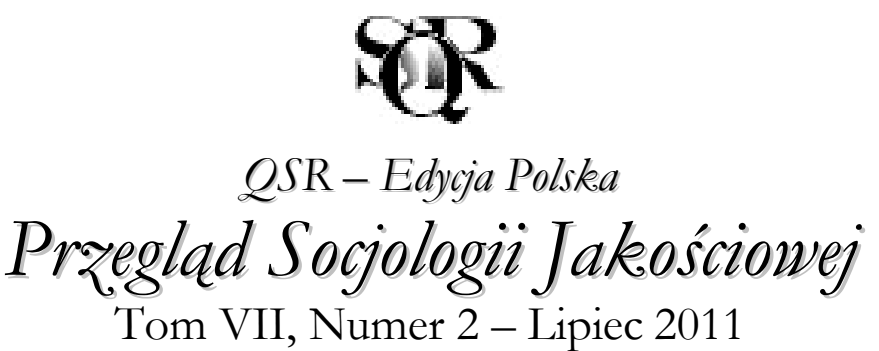

https://doi.org/10.18778/1733-8069.7.2.07

Iza Desperak

Uniwersytet Łódzki, Polska

Perspektywa gender w socjologii a thumaczenia

\begin{abstract}
Abstrakt
Tekst jest poświęcony roli tłumaczeń w tworzeniu i poszerzaniu socjologicznego horyzontu poznawczego. Autorka zwraca w nim uwagę na znaczenie ilości, jakości, aktualności i dostępności przekładów na język polski oraz ich niezbędność. Analizuje funkcje tłumaczeń tekstów dydaktycznych - podręczników i zbiorów tekstów - wyznaczających, obok książek akademickich, kanony socjologicznego mainstreamu. Wskazuje, jak poszerzały one główny nurt socjologiczny o perspektywę gender, wymienia najważniejsze prace $z$ tego zakresu. Analiza obejmuje zarówno przykłady prac do dziś nie przetłumaczonych lub przełożonych zbyt późno, a przez to nieobecnych w kanonie, jak i przetłumaczonych wystarczająco wcześnie, by wejść do kanonu.
\end{abstract}

Słowa kluczowe

Tłumaczenia; gender; kanon socjologiczny

\title{
Perspektywa gender w socjologii a tłumaczenia
}

Rola tłumaczeń w obiegu kultury i myśli jest nie do przecenienia. Dlatego ten tekst jest oparty na analizie tłumaczeń prac socjologicznych, ich publikacji, a także co ważne w analizie jakościowej - ich braku. Nawet dziś, gdy angielski stał się dominującym językiem współczesnej nauki, nie jest on na tyle powszechny, by publikacje anglojęzyczne były automatycznie dostępne mieszkańcom kultur innych języków. Choć już Prusowski bohater, Wokulski, uczył się angielskiego, przeciętny Polak - nawet pracownik nauki - raczej nie czyta w tym języku. Także młode pokolenie, zamieszczające wpisy na portalach społecznościowych po angielsku lub w innych językach obcych, nie posiada masowo umiejętności czytania tekstów, zwłaszcza naukowych, w językach oryginału.

Na ten stan rzeczy wpływa wiele czynników, z których jako pierwszy może być wymieniona żelazna kurtyna, która przez długi czas odcinała nas od kultury zachodniej. Do lat osiemdziesiątych kładziono nacisk na nauczanie obowiązkowego

\footnotetext{
1 Dane adresowe autora: Katedra Socjologii Polityki i Moralności, Instytut Socjologii, Uniwersytet Łódzki, ul. Rewolucji 1905 r. nr 41, 90-214 Łódź

E-Mail: idespera@uni.lodz.pl
} 
rosyjskiego. Wprawdzie Grażyna Kononowicz, od niedawna emerytowana, kierowniczka Biblioteki Socjologicznej im. Józefa Chałasińskiego w Łodzi i absolwentka studiów socjologicznych, wspomina, że w początkach instytucjonalnego nauczania socjologii nie było wcale tłumaczeń i od studentów wymagano czytania tekstów w oryginale, $z$ czym radzili sobie zespołowo, wymieniając między sobą tłumaczenia z różnych języków, jednak ten stan dotyczył prapoczątków Instytutu Socjologii na Uniwersytecie Łódzkim. W latach osiemdziesiątych, gdy ja rozpoczynałam studia socjologiczne w Instytucie Socjologii Uniwersytetu Łódzkiego, poza tłumaczeniami wydanymi przez ówczesne wydawnictwa naukowe uczyliśmy się już na, najczęściej anonimowych, maszynopisach tłumaczeń tekstów obcojęzycznych, dokonanych przez naszych wykładowców.

Mimo postępującej dominacji języka angielskiego, jego znajomość od niedawna staje się standardem. Starsze pokolenia socjologów uczyły się niemieckiego i francuskiego bowiem między Polską a Niemcami czy Polską i Francją funkcjonowały kanały wymiany naukowców lub wymiany informacji. Daniel Beauvois, historyk zajmujący się między innymi Polską, twierdzi, że w latach siedemdziesiątych wszyscy naukowcy, z którymi zetknął się w Polsce, władali językiem francuskim (Beauvois 2010). Różne pokolenia naukowców zostały ukształtowane przez różne standardy językowe, co widać wyraźnie choćby w bibliografiach ich prac. Tempo zmian lingwistycznych standardów jest zawrotne - właściwie wymusza je każda kolejna historyczna transformacja. Dominacja językowa jest jednym ze sposobów oddziaływania Centrum (czy raczej Wallersteinowskiego Rdzenia) na Peryferie. Tempo i kierunki transformacji w naszym zakątku świata są tak szybkie, że trudno byłoby w ciągu jednej kariery naukowej opanować kolejne obowiązujące języki na tyle, by utrzymywać kontakt z literaturą naukową w każdym z nich. Sytuacja ta oddziałuje zarówno na naukowców, jak i studentów.

Żelazna kurtyna ograniczała także dostępność literatury naukowej w językach obcych. Dziś zastępuje ją wolny rynek. Czasopisma i książki obcojęzyczne - kiedyś niedostępne z przyczyn politycznych - dziś są odgrodzone od potencjalnych czytelników barierą ekonomiczną. W dalszym ciągu nie stanowią one elementu czytelniczej codzienności i mimo transformacji politycznej i ekonomicznej zamówienie zagranicznej pracy przez polskiego naukowca nadal wiąże się z licznymi trudnościami. Choć nie ma już politycznej cenzury, książki obcojęzyczne nie przenikają łatwo do naszego obszaru językowego. Barierą jest po pierwsze ich cena - w zachodnioeuropejskich czy amerykańskich wydawnictwach są one droższe od polskich, a ich cenę dodatkowo podnosi koszt wysyłki. Nawet pojawienie się i popularyzacja księgarni internetowych nie ułatwia nam życia - na przykład księgarnia amazon.com do dziś nie prowadzi wysyłki do Polski. Nawet jeśli wykładowca zdobędzie upragnioną książkę w jednym egzemplarzu, nie może jej wprowadzić na listę lektur, ponieważ nie sprowadzi jej biblioteka obsługująca studentów jego uczelni. Zmiany proporcji ilościowych między wykładowcami a studentami zaowocowały zmianami proporcji zakupów bibliotecznych - biblioteki uczelniane $z$ trudem radzą sobie $z$ zaopatrzeniem rosnącej liczby studentów w podręczniki do nowych przedmiotów i dla nowych kierunków studiów oraz z dostosowaniem się do nowych kanonów lektur. Potrzeby naukowców to coraz częściej potrzeby wykładowców - biblioteki kupują głównie podręczniki, a i wydawnictwa naukowe stawiają głównie na nie. Ale nawet tam, gdzie prowadzone są studia w językach obcych, książek anglojęzycznych nie przybywa - na kilkutysięcznym wydziale, gdzie studenci obcojęzyczni stanowią kilka procent, nie 
opłaca się zakupić zestawu podręczników tylko dla nich. Współczesny obieg myśli naukowej to czasopisma. Liczące się magazyny i bazy obecne w Internecie są płatne. Uczelnie polskie, oszczędzające niekiedy na papierze toaletowym i kredzie, nie są w stanie dogonić światowego mainstreamu i sfinansować swym pracownikom dostępu do liczących się współczesnych czasopism zarówno tradycyjnych, jak i online.

Pracownicy ci niestety też nie zawsze mogą sobie pozwolić na dostęp do zagranicznej literatury naukowej. Dla części kadry akademickiej sukcesem jest związanie końca z końcem - zarobki są wciąż żenująco niskie. Niebagatelną rolę w dostępie do zagranicznych publikacji i standardów mają podróże: udział w międzynarodowych konferencjach i wymianach. Jednak barierą dostępu do nich są znów finanse - zarówno budżety uczelni, jak i budżety domowe naukowców. Ograniczenia finansowe dotyczą zwłaszcza młodych kadr - po upowszechnieniu się studiów doktoranckich zanikają etaty asystenckie, a prawie sześćdziesiąt procent doktorantów nie otrzymuje nawet stypendium. Oznacza to, że przeciętny pięcioletni okres przygotowania i pisania doktoratu odbywa się często na granicy biedy, która uniemożliwia zakup publikacji obcojęzycznych za własne pieniądze młodego adepta nauki.

Kształcenie językowe studentów, nawet w stosunku do lat osiemdziesiątych, zostało drastycznie okrojone. Uczelnie zrezygnowały nie tylko z nauczania języka rosyjskiego, ale i francuskiego czy hiszpańskiego. Jednocześnie nastąpiła komercjalizacja nauczania języka angielskiego - uczelnia nie zapewnia nauczania na odpowiednim poziomie, a uczelniane studia językowe stają się coraz częściej przybudówkami prywatnych szkół językowych. Płacenie za naukę języka staje się nowym standardem. Na Uniwersytecie Łódzkim - i pewnie na wielu innych uczelniach - rozwinął się system płatnych egzaminów wewnętrznych zwalniających z obowiązkowego lektoratu. Jednocześnie w porównaniu z latami osiemdziesiątymi, zmniejszyła się liczba godzin nauczania na lektoracie i liczba obowiązkowych lektoratów, a znacznie zwiększyła przeciętna liczba studentów w grupie.

Najlepsi absolwenci trafiają na studia doktoranckie i - nieliczni - na etaty asystenckie. Niestety, przygotowując doktorat, nie mogą liczyć na nadrobienie braków językowych z okresu studiów. Po pierwsze, są już w dość zaawansowanym wieku jak na naukę języka - mają dwadzieścia pięć i więcej lat. Po drugie, dwie piąte doktorantów utrzymujących się z tysiączłotowego stypendium nie może sobie pozwolić na dodatkowe lekcje języków. Pozostała większość, poza robieniem doktoratu i prowadzeniem obowiązkowych zajęć dydaktycznych, zajmuje się zarabianiem na życie, przez co na naukę języków może nie starczyć czasu. W efekcie obowiązkowy egzamin doktorski z języka obcego staje się rytuałem przejścia, a nie potwierdzeniem znajomości języka w stopniu umożliwiającym pracę naukową w danym języku.

\section{Kanon i mainstream}

W tej sytuacji wpływ obcojęzycznych, nietłumaczonych na polski publikacji o zasięgu międzynarodowym jest niewielki. Bazą socjologicznego horyzontu poznawczego pozostają tłumaczenia. Dotyczy to zresztą nie tylko języka angielskiego - recepcja twórczości Pierre’a Bourdieu długo odbywała się na podstawie omówień, opracowań i przekładów nielicznych fragmentów jego tekstów. Prace tego autora dopiero teraz docierają do nas w tłumaczeniu, co powinno wpłynąć 
na jego umocowanie w socjologicznym mainstreamie. Co ciekawe, jednym z najbardziej przystępnych dla polskiego czytelnika okazało się tłumaczenie Męskiej dominacji (Bourdieu 2004) dokonane przez pedagożkę Lucynę Kopciewicz, specjalizującą się zresztą w Bourdieu, co uczyniło jego teorie popularnymi w kanonie nauk o wychowaniu. Fragment tłumaczenia Przemocy symbolicznej (Bourdieu 2005) znalazł się w tomie Lektury - zbiorze tekstów uzupełniających podręcznik socjologii Piotra Sztompki. Ten przykład pokazuje też, jak współczesny kanon socjologiczny coraz częściej odnosi się do wymiaru gender, który będzie dalszym tematem analizy.

Horyzont poznawczy socjologicznego mainstreamu wyznaczają między innymi podręczniki. Nie tylko służą one kształceniu kolejnych pokoleń socjologów, ale wyznaczają ramy mainstreamu, obowiązującego kanonu i standardów. Podstawowym podręcznikom towarzyszą opracowania, listy lektur i opracowania typu „reader”, niestety wciąż dość nieliczne we współczesnej praktyce dydaktycznej.

Choćby ze względu na standaryzację programów nauczania wyznaczają one kanon teorii, nazwisk i tekstów niezbędnych dla funkcjonowania w obrębie socjologii i nauk społecznych. W ten sposób wpływają nie tylko na poznawczy horyzont studentów, ale i ich nauczycieli, którzy, poruszając się w obrębie kanonu, zapuszczają się na jego marginesy raczej w dyskursie wewnątrznaukowym, nie zawsze wychodząc poza ramy seminarium, konferencji czy socjologicznego czasopisma. Oczywiście niezbędnym uzupełnieniem są przekłady książek.

Na standaryzację treści nauczania i kanonu wpływa obecność lub nieobecność tłumaczeń. Od lat obserwuję, jak ulotne wyobrażenia pewnych konceptów stają się niemal ciałem po pojawieniu się polskojęzycznego przekładu. Znamienne są historie tłumaczeń prac Ervinga Goffmana czy wspomnianego już Pierre’a Bourdieu - ich koncepcje były dostępne jedynie nielicznym czytelnikom oryginalnych dzieł, trudno było „upolować” przypis czy cytat. Te prace funkcjonały dzięki omówieniom, często z drugiej czy trzeciej ręki, brak było standardów tłumaczenia terminów. Do dziś nieprzetłumaczony pozostaje Immanuel Wallerstein, nie wspominając mniej znanych, poczynając od Ibn Chalduna. Autor ten pojawia się w socjologicznym kanonie dzięki tłumaczeniu Klasycznej myśli socjologicznej George’a Ritzera (2009), a przecież Ludwik Gumplowicz rozpowszechniał myśl Ibn Chalduna w naszym kręgu kulturowym! Mamy też - na szczęście - tłumaczenie jednej z jego kluczowych prac Muqaddimy, dokonane przez Hassana A. Jamsheera z Uniwersytetu Łódzkiego (Jamsheer 2002).

Nieliczne przekłady są dokonywane przez różnych tłumaczy, współpracujących z różnymi wydawnictwami i tłumaczących z perspektywy różnych orientacji teoretycznych. W rezultacie nie istnieją standardy tłumaczenia kluczowych pojęć nawet w przypadku klasyka Maxa Webera - różne podręczniki posługują się często wymiennie terminami 'władza' i 'panowanie'. Niekiedy odbiór prac tego autora, piszącego w języku niemieckim, ale docierającego do nas także poprzez anglojęzyczne tłumaczenia, opracowania i podręczniki, przypomina analizę błędnej, uproszczonej recepcji myśli Zygmunta Freuda dokonanej przez Brunona Bettelheima (1991).

Tłumaczenia są zresztą zmorą dydaktyków poruszających się na styku socjologii i polityki. Przykładem może być terminologia dotycząca zjawiska kultury politycznej. W polskim tłumaczeniu artykułu Civic culture (Kultura Polityczna [Almond, Verba 1995]), zamieszonym w zbiorze Władza $i$ społeczeństwo pod redakcją J. Szczupaczyńskiego, jedną z form kultury politycznej nazywa się 'parafialną'. W podręczniku politologii Adriana Heywooda (2009) ten sam termin został przetłumaczony jako 'kultura polityczna zaściankowa'. Brak standardów tłumaczeń 
w sferze socjologii polityki i politologii jest nieprzypadkowy - jest to subdyscyplina, której treści dydaktyczne zmieniły się dosłownie w ciągu kilku lat na skutek transformacji politycznej i dopiero teraz następuje przenikanie nowych paradygmatów, pojęć, definicji, klasyfikacji i innych składników nowych teorii.

To samo zjawisko niepewności terminologicznej obserwujemy w przypadku nowych teorii. Jeśli chodzi o Immanuela Wallersteina, to - w zależności od tłumacza - jego koncepcja tłumaczona jest jako 'teoria systemu światowego', 'teoria światosystemu' albo 'systemu-świata'. Teoria Manuela Castellsa długo funkcjonowała jako 'teoria społeczeństwa sieciowego', aż do - spóźnionej - publikacji polskiego tłumaczenia pod tytułem Społeczeństwo sieci (Castells 2007).

\section{Perspektywa gender w socjologii}

Rolę tłumaczeń w tworzeniu i przekształcaniu się socjologicznego kanonu warto prześledzić na przykładzie perspektywy gender. Ta perspektywa była obecna już w prapoczątkach myśli społecznej. Platon rozważa w Państwie (2003) między innymi kwestię równości dostępu kobiet i mężczyzn do zawodów w utopijnym państwie, w swej Polityce Arystoteles (2001) polemizuje ze stanowiskiem Platona, wyznaczając na następne stulecia kanon, w którym standardem jest nierówność. W epoce nowożytnej do kwestii nierówności płci powrócił między innymi John Stuart Mill w Poddaństwie kobiet (1995). Dziś perspektywa gender jest jednym z wymiarów socjologicznej analizy takich prac jak: Siła tożsamości Castellsa (2008), Przemiany intymności Giddensa (2006) czy Wzbierająca fala Ingleharta i Norris (2009). Pojawił się też przetłumaczony z języka angielskiego podręcznik dotyczący socjologii męskości i kobiecości - Kobiety, mężczyźni i społeczeństwo (Renzetti, Curran 2005). Na obecność perspektywy gender we współczesnej socjologii wpłynęły dwa zjawiska: pojawienie się niezależnej i osobnej myśli feministycznej oraz zaistnienie kobiet w socjologii wraz z przemianami samych uniwersytetów, opisane między innymi przez Ritzera (2004). Te kobiety nie od razu poszerzyły kanon socjologiczny o kwestię płci, pionierki napotykały na wiele trudności. Doskonałym przykładem barier, na jakie natrafiały zarówno kobiety - naukowcy, jak i problematyka kobieca, wkraczając do socjologicznego mainstreamu, jest postać i prace Violi Klein. Ta, zmuszona do emigracji z Niemiec, asystentka Mannheima doznała podwójnego wykluczenia - jako kobieta i jako Żydówka. Podczas gdy Mannheim nadal zajmował się na emigracji pracą naukową, Klein była zmuszona do zarabiania na życie jako służba domowa. Te doświadczenia z pewnością wpłynęły na kierunek i charakter jej dalszych prac, Klein została bowiem jedną z założycielek subdyscypliny socjologii pracy kobiet (Klein 1961). Znamienne jest, że prace Klein nie zostały przełożone na język polski, przez co pozostaje ona praktycznie nieznana w naszym kraju.

Brak tłumaczeń prac odnoszących się do perspektywy gender, wywarł wpływ na jej nieobecność lub bardzo opóźnioną obecność w polskim mainstreamie. Dotyczy to zarówno klasycznych prac socjologicznych, jak i tych długo pozostających poza socjologicznym kanonem.

Klasyczną nieprzetłumaczoną pracą stricte socjologiczną jest Gender Advertisements Ervinga Goffmana (1976). To pozycja legenda - mitologiczny utwór, o którym prawie każdy słyszał, ale nikt nie widział, nieobecny w bibliotekach naukowych. Jest to jedna z pierwszych analiz fotografii i reklam, a także chyba pierwsza praca zaliczana do socjologii głównonurtowej, przynajmniej od czasu, gdy znalazło się w niej nazwisko Goffmana. Inaczej niż klasyczna pozycja dla myśli 
feministycznej Feminine Mystique (Frieden 1963), która, choć oparta na swego rodzaju sondażu oraz analizie właśnie treści reklam, nie pretenduje do uznania za pracę stricte socjologiczną, analiza Goffmana jest traktowana jako socjologiczna, a nie feministyczna, choćby ze względu na pozycję autora i jego płeć. Jednak w licznych polskich i tłumaczonych na język polski opracowaniach, dotyczących wkładu Goffmana do współczesnej teorii socjologicznej, ta praca nie jest wymieniana, nie ma jej w programach nauczania Historii Myśli Socjologicznej czy Współczesnych Teorii Socjologicznych. Jest to efekt splotu dwóch niefortunnych przyczyn: niedostępności książki ( $w$ Łodzi nie ma jej żadna biblioteka naukowa) oraz marginalności rozważań, dla których płeć społeczna jest podstawowym wymiarem analizy. Podobnie było z niezwiązaną z gender Stigmą (Goffman 1963) - do polszczyzny trafił termin 'stygmatyzacja', a dopiero po dziesięcioleciach pojawiło się tłumaczenie pod tytułem Piętno (Goffman 2005)! Zapewne gdyby przetłumaczono je wcześniej, podręczniki częściej posługiwałyby się terminem 'napiętnowanie' niż 'stygmatyzacja'.

Do dziś odwoływanie się w socjologii do perspektywy gender przypomina sytuację prac Ervinga Goffmana, przebijających się powoli do polskich wydawnictw, lub Johna Stuarta Milla, którego Poddaństwo kobiet (1995) przetłumaczono na polski w 1869 roku i wznowiono w 1887 (pierwodruk oryginału 1859). Kolejna publikacja tej pracy nastąpiła w 1995 roku na podstawie stuletniego tłumaczenia, jednak książka została wydana $\mathrm{w}$ tak ograniczonym nakładzie, że nawet biblioteka Instytutu Socjologii Uniwersytetu Łódzkiego dysponuje jedynie kserokopią.

Inną ważną pracą dla refleksji nad płcią społeczno-kulturową jest Druga płeć Simone de Beauvoir (1972). Została ona przetłumaczona na początku lat siedemdziesiątych, jednak polskie wydanie nie podbiło ani socjologicznego mainstreamu, ani nawet jego marginesów. Analiza jej ówczesnej recepcji (analiza recenzji z kluczowych opiniotwórczych czasopism i wywiadów z socjolożkami zajmującymi się wówczas problematyką kobiecą) wskazuje, że została ona zignorowana przez środowisko socjologiczne. Być może stało się tak dlatego, że autorka funkcjonowała $w$ opinii publicznej jako pisarka beletrystka, oraz partnerka filozofa, intelektualisty Sartre’a, a być może dlatego, że autorka opisuje socjalizację do ról płciowych, nie używając ani terminu 'socjalizacja', ani 'rola'.

Druga płeć de Beauvoir (1972) wraz z Feminine Mystique Betty Friedan (1963) to podstawowe założycielskie teksty dla feminizmu drugiej fali - ruchu, który zainspirował socjologię feministyczną i rozwój perspektywy gender w socjologii (Desperak 2010). Drugą płeć przetłumaczono, a nawet po latach wznowiono. Jednak Feminine Mystique z 1963 roku do dziś nie przetłumaczono na polski. Nie może się zatem znaleźć na listach studenckich lektur ani - co za tym idzie - w bibliotekach. W efekcie zasięg oddziaływania tej pracy jest niewielki. Książka doczekała się wielu wydań, jest obecna w anglojęzycznym obiegu antykwarycznym i na aukcjach internetowych, które jednak nie obejmują swym zasięgiem Polski, co oznacza, że skomplikowaną procedurę zakupu za pośrednictwem znajomych wykona tylko niewielu wyjątkowych zapaleńców. W „Res Publice Nowej” ukazał się jak dotąd krótki fragment Feminine Mystique (Friedan 2008) przetłumaczony przez Agnieszkę Graff, a wydawnictwo Diffin przygotowuje podobno - spóźnione o półwiecze - wydanie polskiego tłumaczenia.

Obok wspomnianych wyżej podręczników i „readerów” kwestia tłumaczeń i ich braku przekłada się na poznawczy i teoretyczny horyzont socjologiczny, zarówno młodego pokolenia, jak i dojrzałych naukowców. Jeszcze mniej na socjologiczny 
horyzont wpływają prace specjalistyczne wydane niegdyś w małych nakładach, a obecnie nie wznawiane.

Przykładem może być obszar teorii socjobiologicznych. Funkcjonują liczne prace, często o charakterze dalekim od naukowego, ukazujące wyłącznie seksistowskie oblicze socjobiologicznej analizy relacji między płciami, od dość rzetelnego jeszcze Desmonda Morrisa (1974; 2006), poprzez pełną błędów i przekłamań, które umknęły redakcji wydawnictwa naukowego, pracę Anne Moir i Davida Jessela Płeć mózgu (1993), po teksty popularnonaukowe, które swą prostotą zwodzą czytelników na manowce. Brak jest natomiast nie tylko tłumaczeń, ale także wiedzy o istnieniu innego oblicza socjobiologii, akceptowanego czy wręcz inspirowanego przez myśl feministyczną i współczesną refleksję o płci społecznej. Te prace, podobnie jak Pochodzenie kobiety i Blizny po ewolucji Elaine Morgan (2007; 2010), są obecnie tłumaczone na język polski, jednak pojawia się wątpliwość, czy po czterdziestu latach od ich pierwotnego wydania mogą nadgonić braki w recepcji, zyskać popularność równą Płci mózgu (Moir, Jessel 1993) i uzupełnić horyzont poznawczy czytelników prac Desmonda Morrisa (czyli kilkunastu roczników studentów socjologii Uniwersytetu Łódzkiego oraz kilkunastu innych uczelni)? Czy spóźnione tłumaczenie Feminine Mystique (Friedan 1963) mogłoby poszerzyć horyzonty współczesnego czytelnika mającego dostęp do dzieł feminizmu drugiej fali, nowego feminizmu i postfeminizmu? Czy dzięki niemu mówilibyśmy dziś o „mistyce kobiecości"? Czy pojawienie się (z czterdziestoletnim opóźnieniem) tłumaczenia Gender Advertisements Ervinga Goffmana (1976) wzbogaciłoby odbiorcę współczesnej kultury masowej, który na portalu ściąga.pl znajdzie kilkadziesiąt opracowań na temat wizerunku kobiet i mężczyzn w reklamie? Termin 'stygmatyzacja' pojawił się przecież, i to w powszechnym użyciu, dzięki temu, że Stigma Goffmana (1963) nie funkcjonowała jako Piętno (2005). Także teoria społeczeństwa sieciowego Castellsa weszła do programów nauczania teorii socjologicznych kilka lat przed ukazaniem się tłumaczenia Społeczeństwa sieci (2007).

Obok wymienienia kluczowych prac nieprzetłumaczonych na język polski i niewydanych w Polsce należy zwrócić uwagę na rolę tłumaczeń i edycji polskich. Bardzo pouczające są losy tłumaczenia Drugiej płci Simone de Beauvoir. Jej wartość pozostawała długo niedoceniona. Ani autor wstępu do pierwszego wydania (1972), ani autorzy recenzji w ówczesnych czasopismach opinii nie zwrócili uwagi na zarysowaną w niej analizę społecznych nierówności płci, i ich kontekstu historycznego, ekonomicznego i społecznego właśnie, zaliczając pracę do nurtu filozofii egzystencjalistycznej, refleksji poświeconej mitom bądź potocznych rozmyślań pisarki o kobiecym losie. Recenzje Drugiej płci, które ukazały się (w pierwszej połowie marca 1973 roku, co mogło wiązać się z obchodzonym ósmego marca Dniem Kobiet) w liczących się wówczas opiniotwórczych czasopismach, również pomijają tę perspektywę. Większość recenzji dyskredytuje pracę, ośmiesza ją, traktuje jako ósmomarcową ciekawostkę. Jeden z recenzentów sprowadzą pracę tę do „pisarstwa damskiego”, gdzie „wszystko upchane kolanem: majtki, pończochy, portreciki mężów, fotografie, przepisy na zupę nic i budyń, kalendarzyk według metody Ogino - Knauss" (Desperak 2010). Druga płeć (de Beauvoir 1972) była odczytywana co najwyżej jako dzieło z pogranicza filozofii i seksuologii i nie doczekała się rzetelnej dyskusji. Zarzuty pojawiające się na łamach czasopism nie miały charakteru merytorycznego, obnażyły raczej ignorancję i paternalizm recenzentów. Praca nie została odnotowana przez wychodzące wówczas czasopisma socjologiczne, nie odnoszą się do niej autorzy i autorki publikowanych 
w latach siedemdziesiątych polskich prac socjologicznych dotyczących płci i kobiecości. Również trzy wywiady, które przeprowadziłam z aktywnymi do dziś socjolożkami zajmującymi w swoim czasie się problematyką kobiet, dowodzą, że, $z$ różnych powodów, książka ta nie wywarła wpływu na ich intelektualny horyzont.

Co ciekawe, w publikowanych w tym czasie tłumaczeniach też nie pojawiają się odniesienia do książki de Beauvoir, na przykład w Kobiecie w świecie współczesnym Kathleen Newland (1982) znajdują się odniesienia do Betty Friedan, a także innych autorek drugiej fali feminizmu: Susan Brownmiller, Gayle Tuchman czy ważnej publikacji adresowanej do szerokiej publiczności Our Bodies, Ourselves (1984) (wydanej w języku polskim jako Nasze ciała, nasze życie dopiero w 2004 roku), natomiast nie ma odniesień do Drugiej płci - a więc przemilczano ją w owym czasie nie tylko po polsku. Może to wynikać ze ściśle anglojęzycznego zaplecza Newland, jednak Druga płeć została wydana po angielsku już w 1953 roku. Innym powodem tej znaczącej nieobecności może być specyfika anglojęzycznej myśli feministycznej i genderowej, która - jak diagnozuje Christine Delphy - z entuzjazmem zaadoptowała z obszaru myśli francuskiej prace Jacques'a Lacana, Julii Kristevy, Hélène Cixous, Jacques'a Derridy czy Luce Irigaray, ignorując prace z nurtu feminizmu materialistycznego, do którego zalicza się też de Beauvoir (Delphy 1995). Co ciekawe, cytowane dzieło Newland ukazało się pod tytułem daleko odbiegającym od oryginalnego: The Sisterhood of Men. The Impact of Women's Changing Roles on Social and Economic Life Around the World, co może świadczyć o próbie umieszczenia rozważań odwołujących się do myśli feministycznej w mainstreamowej stylistyce "twardych" empirycznych publikacji.

Mimo początkowego braku zainteresowania, książka de Beauvoir została wznowiona w 2003 roku, a sformułowanie „nikt nie rodzi się kobietą” posłużyło jako tytuł pierwszej polskiej antologii tekstów feministycznych, przygotowanej przez Teresę Hołówkę (1982). Dyskurs feministyczny i genderowy rozwijał się w Polsce między innymi dzięki tłumaczeniom - już od lat osiemdziesiątych, w latach dziewięćdziesiątych następuje jego rozszerzenie $z$ nisz feministycznych i intelektualnych. O gender piszą filozofowie, językoznawcy, socjologowie. W 1995 roku ukazuje się pierwsze stricte socjologiczne opracowanie wyznaczające standardy swym następcom: Co to znaczy być kobietą w Polsce? (1995). Zauważmy, że ten standard to wciąż większe zainteresowanie społeczną sytuacją kobiet niż fenomenem konstruowania płci społecznej. Pod koniec lat dziewięćdziesiątych i w latach dwutysięcznych następuje trwałe ulokowanie się problematyki gender w dyskursie naukowym, publicystycznym i potocznym, nie ograniczonym już do marginesów, lecz zmierzającym $w$ stronę mainstreamu. W międzyczasie na horyzoncie owych dyskursów pojawiają się zarówno opóźnione o kilkadziesiąt lat publikacje klasyki feministycznej lat siedemdziesiątych, jak i późniejsza myśl postfeministyczna. Niekiedy prace powstałe niedawno nie znajdują oddźwięku dlatego, że polemizują z dziełami z pośrednich etapów rozwoju dyskursu, nieprzełożonymi na język polski. Przykładem takiej polemiki z nieobecnymi w opóźnionym polskim dyskursie dyskursie reprezentantkami poprzedniej fali myśli femistycznej jest polskie tłumaczenie Fałszywej ścieżki Elizabeth Badinter (2005), która krytycznie odnosi się do prac i poglądów nieznanych w Polsce. 


\section{Bibliografia}

Almond, Gabriel i Sydney Verba (1995) "Kultura politczna". S. 328-344 w: Władza i społeczeństwo, pod redakcją J. Szczupaczyński. Warszawa: Scholar.

Arystoteles (2001) Polityka. Warszawa: PWN.

Badinter, Elizabeth (2005) Fałszywa ścieżka. Przełożyła M. Kozłowska. Warszawa: WAB.

Beauvoir de, Simone (1972) Druga płeć. Przełożyła G. Mycielska. Kraków: Wydawnictwo Literackie.

Beauvois, Daniel (2010) "Chłopów bili po twarzy". Gazeta Wyborcza z dnia 18/19 $\begin{array}{llll}\text { sierpnia } 2010 \mathrm{r} \text {. } & \text { Dostęp sierpień, } & 2010\end{array}$ (http://wyborcza.pl/1,76842,8304931,Chlopow_bili_po_twarzy.html).

Bettelheim, Bruno (1991) Freud i dusza ludzka. Przełożyła D. Danek. Warszawa: PIW.

Bourdieu, Pierre (2004) Męska dominacja. Przełożyła L. Kopciewicz. Warszawa: Wydawnictwo Oficyna Naukowa.

----- (2005) „Przemoc symboliczna”. S. 503-508 w: Socjologia. Lektury, pod redakcją P. Sztompki i M. Kucia. Kraków: Wydawnictwo Znak.

Castells Manuel (2007) Społeczeństwo sieci. Przełoźyli K. Pawluś, M. Marody, J. Stawiński. Warszawa: PWN.

------ (2008) Siła tożsamości. Przełożył S. Szymański. Warszawa: Wydawnictwo Naukowe PWN.

Domański, Henryk i Anna Titkow redaktorzy (1995) Co to znaczy być kobietą w Polsce? Warszawa: IFiS PAN.

Delphy, Christine (1995) "The Invention of French Feminism: An Essential Move." S. 190-221 w: Another Look, Another Woman: Retranslations of French Feminism, Yale French Studies (87).

Desperak, Iza (2010) Recepcja „Drugiej płci” Simone de Beauvoir w Polsce. Perspektywa socjologiczna. (www.feminoteka.pl/readarticle.php?article_id=920).

Friedan, Betty (1963) Feminine Mystique. Harmondsworth: Penguin Books. (2008) "Mistyka kobiecości". Res Publica Nowa (4): 145-152.

Giddens, Anthony (2006) Przemiany intymności. Seksualność, miłość i erotyzm we współczesnych społeczeństwach. Przełożyła A. Szulżycka. Warszawa: Wydawnictwo Naukowe PWN.

Goffman, Erving (1976) Gender Advertisements. Londyn: MacMillan.

----- (2005) Piętno. Rozważania o zranionej tożsamości. Przełożyły A. Dzierżyńska, J. Tokarska-Bakir. Gdańsk: Gdańskie Wydawnictwo Psychologiczne.

Heywood, Andrew (2009) Politologia. Przełożyli M. Kornobis, P. Kornobis, K. Wolański. Warszawa: Wydawnictwo Naukowe PWN.

Hołówka, Teresa, redaktor (1982) Nikt nie rodzi się kobietą. Warszawa: Czytelnik. 
Inglehart, Ronald i Pippa Norris (2009) Wzbierająca fala: równouprawnienie płci a zmiana kulturowa na świecie. Przełożyła B. Hellmann. Warszawa: PIW.

Jamsheer, Hassan Ali (2002) Ibn Chaldun i jego Muqaddima: antologia myśli społeczno-politycznej. Łódź: Ibidem.

Klein, Viola (1961) Employing married women. Londyn: Institute of Personnel Management.

Mill, John Stuart (1995) "Poddaństwo kobiet". S. 283-384 w: O rządzie reprezentatywnym. Poddaństwo kobiet. Kraków: Znak.

Moir, Anne i David Jessel (1993) Płeć mózgu: o prawdziwej różnicy między mężczyzną a kobietą. Przełożyła N. Kancewicz-Hoffman. Warszawa: PIW.

Morgan, Elaine (2007) Pochodzenie kobiety. Przełożyła M. Danicka-Kosut. Warszawa: Anadiomene.

(2010) Blizny po ewolucji: co nasze ciała mówią nam o pochodzeniu człowieka. Przełożyła M. Danicka-Kosut. Warszawa: Anadiomene.

Morris, Desmond (1974) Naga małpa. Przełożył T. Bielicki. Warszawa: Wiedza Powszechna.

----- (2006) Naga kobieta. Przełożył P. Amsterdamski. Warszawa: Wydawnictwo Albatros.

Newland, Kathleen (1982) Kobieta w świecie współczesnym. Przełożył Z. Stępniewski. Warszawa: Państwowe Wydawnictwo Ekonomiczne.

Nowak, Barbara (1973) "O radosnym brudzie". Tygodnik Kulturalny (10): 4.

Our bodies, ourselves (1984). Boston: Boston Women's Health Book Collective; wydanie polskie Nasze ciała, nasze życie (2004). Gdańsk: Stowarzyszenie Współpracy Kobiet NEWW - Polska.

Platon (2003) Państwo. Przełożył W. Witwicki. Kęty: Wydawnictwo Antyk.

Renzetti, Claire M. i Daniel J. Curran (2005) Kobiety, mężczyźni i społeczeństwo. Przełożyła A. Gromkowska-Melosik. Warszawa: Wydawnictwo Naukowe PWN.

Ritzer, George (2004) Klasyczna teoria socjologiczna. Poznań: Zysk i Spółka.

\section{Cytowanie}

Desperak, Izabela (2011) "Perspektywa gender w socjologii a tłumaczenia". Przegląd Socjologii Jakościowej, Tom VII Numer 2. Pobrany Miesiąc, Rok (http://www.qualitativesociologyreview.org/PL/archive_pl.php) 